\title{
CHALLENGES OF SUSTAINABLE TOURISM IN ANCIENT CITIES: A CASE STUDY BASED ON KANDY, SRI LANKA
}

\author{
S. Sivesan \\ sivesanuni@yahoo.com \\ Department of Marketing \\ University of Jaffna - Sri Lanka
}

\begin{abstract}
Within the extensive body of tourism literature, successful implication of sustainable tourism and obstacles to its practices in the developing world are emerging themes. This paper critically investigates challenges to sustainable tourism in the world heritage sites with special references to Kandy situated in Central Province of Sri Lanka. Through adopting a qualitative research method, a key issue for discussion in this paper is challenge to sustainable tourism in Kandy. Consequently, this paper provides an insight into sustainable tourism and suggests the ways by which these insights may be useful in the provision of sustainable tourism in other ancient heritage localities.
\end{abstract}

Keywords: sustainable tourism, destruction of cultural heritage building, tourism infrastructure

\section{Introduction}

This paper is mainly to investigate challenges that are associated with sustainable tourism in Kandy, Sri Lanka. In fact, this is timely very limited number of studies available that deal specifically with Sri Lankan heritage destinations. It is intended that the findings of this paper provide an insights to understand ground situations connected with tourism development in the ancient city of Kandy. Throughout the island following the declaration of peace in 2009, the tourism industry has been gradually developing. Recently, policy makers and practitioners in Sri Lanka have turned their attention to sustainable tourism or sustainable tourism development. Researchers including, Ladkin and Bertramini (2002), Sharpley et al. (2014) and Tosun (2001) who argued that recently many developing countries and small islands have benefited from shared and collaborative works of the multiple - stakeholder approached that has been the focus of sustainable tourism. 
Sri Lanka offers a variety of cultural heritage, natural and recreational products. In Sri Lanka eight sites have been listed as world heritage sites. Of these, six sites are cultural heritage sites (including Kandy). The other two are natural sites. All sites are regarded as major tourism resources that have contributed towards the creation of a positive branding of Sri Lanka as a tourist destination for global travellers. Present-day, travelers to Sri Lanka continues to boom. For example, tourist arrivals to Sri Lanka during the first six month of 2016 were 964,267 and it was an increase of 16.2 percent as against the comparable period of the previous year. It is estimated that the tourist arrivals will reach 4 million in 2020. India was the prime tourist generating county to Sri Lanka in 2014 and 2015 and the market is still growing. The foreign exchange earnings from tourism also increased by 20.12 percent from US $\$ 2,431$ million in 2014 to US \$2,920 million in 2015 (Sri Lanka Tourism Development Authority, 2016). As pointed earlier, according to the Ministry of Tourism Development, Land and Christian Affairs has set tourism targets to achieve by 2020: 4 million visitor arrivals, tourism revenue to be in excess of US $\$ 5$ billion and room inventory to be 45,000 .

As a concept sustainable tourism is a contested concept in practitioner and scholarly forums (Berry \& Ladkin, 1997; Bramwell \& Lane, 2015; Hunter, 1997). Sustainability has evolved from a narrow conservation focus perspective that drew on nineteenth-century thought into a modern sub-discipline that emphasizes resource issues and technical, economic, social and political processes. For Archer, Cooper, and Ruhanen (2005), sustain ability is a core concept in the re-evaluation of the contribution of tourism to host communities. Sustainable tourism is a holistic approach, and also used to create a long-standing balance among environmental, socio cultural and economic aspects in the context of tourism development (Hall, 2003). For Cater (1993) a sustainable tourism approach should be exercised in the worldwide tourism market. These include promotion the standard of living of stakeholders, community cohesion, tourism infrastructure and protection of cultural heritage. In this respect sustainable tourism closely aligns with sociocultural development of host community. More importantly, the implementation of an appropriate sustainable tourism plan enables better preservation of natural and cultural heritage.

\section{Unraveling Sustainable Development and Sustainable Tourism}

Although conceptualization of sustainable development is awkward, heterogeneous scholars have accepted the concept. Liu (2003, p. 461) argued that: 
Sustainable development is more process-oriented and associated with managed changes that bring about improvement in conditions for those involvements in conditions for those involved in such development.

In line with this assertion, it could be perceived that, sustainable development involves with management of resources, in order to meet community's requirements. Noted by Hop wood, Mellor and O'Brien, (2005, p. 39).

The concept of sustainable development is the result of the growing awareness of the global links between mounting environmental problems, socio-economic issues to do with poverty and inequality and concerns about a healthy future for humanity.

This definition links improving human well-being with the ecological system. Really, economics and socio culture came to be governing issues of host community relations with booming economies in the world. During the past three decades, sustainable tourism has become a catchphrase throughout development studies as well as within the tourism discipline. Sharpley (2002) has argued that sustainable tourism has become divorced from sustainable development. In fact, the concept of sustainable tourism should be best understood as a subsidiary model derived from the parental concepts of sustainable development. In the literature, sustain ability, sustainable tourism development and sustainable development are ecologically well defined but some researchers argue that the clearly drawn distinctions are being ignored (Liu, 2003; Sharpley, 2002).

The notion of the term of sustainable tourism has been conceptualized by many scholars and international organizations. For example, Bramwell (2015, p. 204) notes that "sustainable tourism is regularly linked with the preservation of ecosystems, the promotion of human welfare, inter and intra-generational equity, and public participation in decision-making". Such improvements facilitate regional and national development. The extant literature suggests that "sustainable tourism is a positive approach intended to reduce the tensions and frictions created by the complex interactions between the tourism industry, visitors, the environment and the communities which are host to holiday makers" (Gupta, 1999, p. 207). This perception described that handling conflicts generated by integration participant of different stakeholders with various expectation in tourism. Sustainable tourism is a living environmental concept that talks not only about environment protection planning but also, in the context of tourism, maintains equity of the sociocultural and economic development of the community (Janusz \& Bajdor, 2013, p. 529). Sustainable tourism 
is strongly connected with basic elements of community such as economic, sociocultural and environmental issues (Bramwell, 2015; Dinica, 2008; Hall, 2011).

From international organizations' point view, UNWTO's thought expressed in Sustainable Tourism for Development - Guide Book indicates "make optimal use of environmental resources that constitute a key element in tourism development, maintaining essential ecological processes and helping to conserve natural heritage and biodiversity" (United Nation World Tourism Organisation, 2013, p. 17). For the UNWTO sustainable tourism is regarded as a management tool for building environmental sustain ability, and safeguarding traditional tourism resources (cultural heritage landscape and climate change). This content is accepted by Drost (1996), who further emphasis the main objective of the sustainable tourism in world heritage sites conserves the cultural heritage and also thrives in and around the sites. As celebrated by McKercher (1993), through application of effective sustainable tourism plan, the foundation can be formed to maintain a balance among available resources, and also to build economically and socially well-organized community.

Similarly, in 2005, UNWTO and UNEP have jointly defined sustainable tourism as "tourism that takes full account of its current and future economic, social and environmental impacts, addressing the needs of visitors, the industry, the environment and host communities" United Nation Environment Programme and World Tourism Organisation $(2005$, p. 12). According to this definition, sustainable tourism has two main functions - managing the visitors' requests and tourist resources in order to control adverse economy and sociocultural impacts. Effectively this means tourism resources should be preserved for future users. Sociocultural impacts emphasises tourists behavior.

\section{Study Methods}

In this paper, a qualitative research method, which has been used, is commonly adopted in tourism studies (Cheer, Reeves, \& Laing, 2013; Wan, 2013). This research comprises two phases. Phase - one concentrated upon document analysis. In this paper, using document analysis, information has been gathered from secondary sources such as Sri Lanka Tourism Development Authority reports, gazettes notification, and Sri Lanka Tourism Act. Merriam (2002) and Bowen (2009) emphasized that document analysis is a most significant sophisticated data collection technique used in qualitative research. Through this method of data collection, required information could be met. Such information offers a strong an insights to 
understand holistic framework of the Sri Lankan tourism industry. Figure 1 illustrates the two phases of data collection method.

Phase 2 engaged with filed visit interviews and indirect observation during fieldwork.

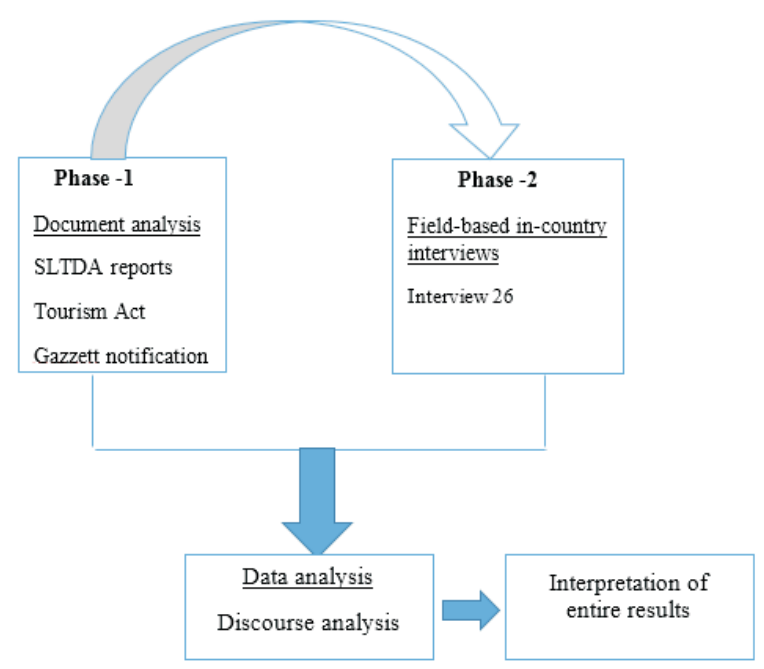

Figure 1: Research Method During the period July to October in 2018, data was collected through field-based in-country interviews as this approach allows respondents to offer more data and to include their feelings, attitudes and understanding of the subject. A total of 26 semistructured interviews were under taken with the main stakehoders (central and provincial government employees, travel agents, hoteliest, tourist guides, tourists and tourism related business people). In the literature researchers Wang and Bramwell (2012), Wan (2013) and Alipour, Vaziri, and Ligay (2011) who used semistructure interview method to collect information. Snowball sample, which was used to select respondents, is non-probability techniques. It is employed in qualitative tourism researches. The evidence, Cheer et al. (2013) used a snowball sample in their research. Discorse analysis methods has been used to make a central argument of this paper. Discourse analysis method is exclusively used to meet the objectives of this research paper. It is a idiosyncratic technique to the qualitative data analysis. Discourse analysis explores that globe is formed by communication with social actors (Fairclough, Mulderrig, \& Wodak, 2011; Lupton, 1992). In this paper, as discussed earlier, data derive from interviews and document analysis undertaken during fieldwork. These data was investigated by discourse analysis.

\section{Case Study}

\section{Tourism industry in Kandy}

Situated in Central Province, the city of Kandy is located in a valley surrounded by green hill side slopes with synthetic lake and is bounded by the river Mahaweli on three sides with the Hantance range on the other. Indeed, Kandy, significant cultural heritage city of Sri Lanka is renowned as one of world heritage city (see figure 2). 
Kandy still retains the vestiges of the rites and rituals of the lost kingdoms of the Sri Lankan people and has colonial historical remains. Further, it is considered as a living cultural heritage city like Angkor (Miura, 2010). The city has great cultural heritage, natural and religious destinations. For example, Udawattakele forest, open parks, the Second World War cemetery and the famous Buddhist temple, which contains tooth relic of Lord Buddha.

Tourism in Kandy is characterized by several positive features. In other words, Kandy has certain opportunities to expand the tourism industry. These are: Kandy as a tourist destination provides many diversified touristic products. Actually, the significance of diversification of tourism products, within the tourism literature, has been debated. For instance; Robinson and Jarvie (2008) note that in the case of Sri Lanka, tourists search new tourist product to gain different experience. In addition, tourist product diversification can increase the demands and promote longer in-country vacations. Field visits and interviews confirmed that Kandy as tourist destination offers many tourists products. In Kandy, all auxiliary services and amenities are in place to attract to support tourists such as medical facilities, educational opportunities, financial sectors services (domestic and international banks), legal services and transport. Another important opportunity is a cultural and religious festivals, which contribute importantly to cultural heritage tourism in Kandy. Many cultural and religious festivals take place annually at different period for diverse reasons. They comprise Kandy Esala Perahera, Vesak, Thai Pongal, Sri Lankan New Year, Deepavali and Christmas. Such festivals attract many tourists annually. Kandy in Sri Lanka is a second large commercial city and it is a big market for heritage products include handicraft and heritage accommodation. International tourists make quite a demand for branded tea, coffee and spices. These sorts of opportunities are very significant factors to promote the tourism industry.

\section{Discussion}

The results of this paper provide some evidence that impediments in Kandy are 
connected with sustainable tourism. The concept of sustainability has become the most important concern but sustainability of course, is a complex issue (Drost, 1996; Landorf, 2009; Liu, 2003; McKercher, 1999; Robinson, 1999). Some researchers have the question the reality of the concept of sustainability (Briassoulis, 2002; Fyall \& Garrod, 1998; Jamieson, 2000; McMinn, 1997). The research findings derive from interviews and document analysis undertaken during fieldwork. The empirical findings of the paper comprise information from many different stakeholders - those who have legal responsibility to be involved in tourism development - who belong to distinct spheres of influence and interest, and who have differing visions concerning their involvement in tourism development.

\section{Infrastructure Facilities}

The basic infrastructure facilities are necessary to attract tourists to key destinations. In other words, the characteristics of tourist destinations are not only determinant factor of success of the tourist destinations but also availability basic needs to fulfill tourist's routine requirements (Prideaux, 2000). Geographically, Sri Lanka is relatively distant from main the tourist generating counties and until recently, this was exacerbated by a lack of direct flights services to Colombo as nearly all visitors needed to repute through India, Singapore, Bangkok, Malaysia and Dubai. Interview with stakeholder highlighted that to increase the tourist arrivals to Kandy it is important to have easy access. Senior officer from Department of Cultural, Tourism, Trade and Commerce Affairs she confirmed that "at present road transport is the most popular mode of transport to Kandy. However, there is no speed highway from Kandy to Colombo and also no air travel access". That means, in Kandy, there is no airport, it has become a serious drawback in tourism development process. Further, there are no express highway, and intercity express rain with air condition, from Colombo to Kandy. Transport services, in fact, are more crucial to tourists' experience because they either facilitate or inhibit the convenience and accessibility of attractions. As noted by Masson and Petiot (2009), historically, after the birth of transport services (air, sea and land), mass tourism became an important concept among leisure devotees in the real world. In addition to that, well developed transport services can draw the attentions of not only tourists but also investors. Traffic and pollution were raised throughout interview as key problem that need to be addressed. The quality, availability, cleanlines and value of accommodation are more significant aspect to the tourism industry throughout the world. These issues in the context of accommodation are making progress, albeit rather slowly. One of the tourists share notion from his 
experiences that "I think that the tourism industry in Kandy should concentrates upon physical infrastructure development including, hygienic and provision of proper information services to tourists". In Kandy, there is no any international branded hotel in Kandy. Indeed, this problem is strongly indicated by many stakeholders. But, policy makers pointed that high spending capacity tourist arrival to Sri Lanka are expected to earn large amount of foreign exchange. If high spending tourists need to be impressed. Attention should be paid to increase the capacity of accommodation, in particularly establishment of universally reputed branded hotels in Kandy. Tourists' view, they are expecting user friendly to access mode to destinations. It is one of significant factor to determine the tourists' satisfaction, and to create brand images. In Kandy, many street direction boards and notice boards have been written in Sinhala language. It is a cause to create communication gaps among many travellers in reaching their destination.

\section{Tensions within Tourism Administration in Kandy}

The Sri Lankan government has taken action to develop the tourism sector at national and provincial level, but political instability and human conflict has adversely influenced the viability of the tourism industry. As noted by Wickramasinghe and Takano (2010) and Powell, Cuschnir, and Peiris (2009), in case of Sri Lanka, there have been a number of challenges including lack of coordination in tourism management, political instability, unwanted religious interference in management of heritage destinations all of which negatively affect sustainable tourism.

The Sri Lankan Tourism has overall central control of the tourism administration. This has, in turn, led to over long delays in decision-making, and created the opportunity for political interference. Traditionally, Kandy is the seat for much political patronage due to its religious significance. Therefore, the ruling political party directly and indirectly can and does influence the development of tourism. It can be recognized that tourism strategies and tourism plans should be developed based on nature of macro - and micro-environmental factors. These are essential to meet an expected development in and around Kandy. Further, they believed that in order to achieve sustainable tourism in Kandy, existing approaches to sustainable tourism development is to be redesigned with the holistic system of the community participants and eco-friendly environmental plans.

Another important problem is a lack of consistency in policy creation and implementation. For example, hoteliers indicated that government fails to keep a consistency in tax policy and incentive system. These contradictions led to impact on 
profitability and success of the hotel industry. Through interviews with the policy makers of Sri Lanka Tourism Development Authority, another important challenge can be recognized that the arrival of high spending capacity tourists are expected and highly encouraged. Through Adoption of this strategy in the future, Sri Lanka may lose their less developed and developing countries' tourists, because South Asian countries, including India and Maldives, the Sri Lankan tourist market are found to be dominated continuously. The evidence is that according to the SLTDA, "the top ten markets accounted almost 65.0 per cent of the total tourist traffic to the country in 2014” Sri Lanka Tourism Development Authority (2015, p. 8). However, per capital income of South Asian country is less than $\$ 2,000$. This approach shows clearly narrow thinking of the policy makers.

Another important challenge to sustain ability of the tourism industry in Kandy is that inefficient promotional strategy is implemented. It is confirmed by hoteliers and travel agents who are not satisfied with promotional works done by Sri Lanka Tourism Promotion Bureau (SLTP). In addition to that, one of the hoteliers critically commanded that "small and medium operators have been impressed about promotional work done by SLPB, while larger scale operators have some negative remarks". In fact, present - day, throughout the country, small and medium hoteliers are receiving reasonable number of tourist for night when compared with larger-scale operators. As the result, large-scale operators are gaining either lower profit or loss.

\section{Regional and National Competitions}

Globally the tourism industry has been developed with high completive advantages. Many countries especially neighbouring countries like Nepal, India and the Maldives became competitors for Sri Lanka. For example the Maldives has many beaches. As the result, it became a popular island tourism destination in Asia. Wickramasinghe et al. (2010) observed that regional countries supply better tourist products to international visitors and that in the last few decades, Sri Lanka as a tourist destination has failed to develop its competitive capacity to meet their regional competitors. An interviewer from Sri Lanka Convention Bureau she confirmed that "critical to the development of tourism in Sri Lanka is a realization that tourism in all South Asia is well-developed”. In fact, during Civil War period (1982-2009), tourism industry collapsed due to political instability, economic crises and lower tourist arrivals. Many foreign governments suggested their citizens to stop to travel to Sri Lanka. These sorts of issues have become major barriers to tourism development in Sri Lanka. 
Meanwhile, such issues generate positive roots to improve the tourism industry in other regional countries. However, it can be seen that present-day, post-war tourism has improved because, the tourist would prefer to visit the war affected areas particularly the northern regions of Sri Lanka. Fernando, Bandara, and Smith (2013) observe that domestic and international traveler to the Northern Province continued to increase. Generally, in many countries including Sri Lanka, Cambodia and Vietnam, after Civil War, the tourism business is started to boom. For this growth, The Australian researchers Logan and Reeves $(2008$, p. 4) have strongly justified that "governments, military groups and people who lost family members and close friends in wars over last century have interest in keeping memories alive, and war related tourism to places like Flanders has grown enormously in recent decades"

\section{Community Relations and Tourism Awareness}

Importantly, sustainable tourism development should be incorporated into national and local development strategies. Host-community participation is to be an important factor for sustainable tourism development because "the host community is the destination in which individual, business and government goals become the tangible products and images of the industry" (Haywood, 1988, p. 106). However, among local people, there is a general fear that tourists destroy our culture by popularizing drugs, alcohol, prostitution and homosexuality. It all depends on the destination management and commitment by the local social; group for not allowing such activities to take place in their area. This is where there need to be an effective community relations and tourism awareness campaigns. Sri Lanka based researcher Ratnapala (1984) points out that homosexuality, prostitution, drug addiction, he highlighted that younger generation of these areas was under the demonstration effect of tourism, creating a threat to the traditional norms and values of the society.

People involved in tourism development, have a responsibility towards the local community to ensure that these anti-social activities does not take place as a result of foreigners visiting Sri Lanka. Host community believed that tourism development may create many environmental problems, unauthorized buildings in pristine natural areas, overcrowding and noise pollutions. These issues need to be addressed separately with the relevant government departments to ensure the rules and regulations are strictly imposed. Attitude within a host community towards tourists and tourism development should be changed. Practically, many community based projects need to be implemented. This, in turn, makes the changes of attitude of 
community. It is an interested to note here that a German based tourist described attitude of host community that "some Sri Lankan think that all western tourists are bringing lots of money, and the task of tourism is to get their money". This type narrow thinking of community that can and did negatively reflect on their interactions with tourists. Awareness to host community is to be enhanced.

\section{People and Settlement Expansion in City}

Generally speaking, globalization and population expansion are affecting all sectors of the tourism industry largely because it is turning the world into one big travel market. All over the world, population growth and mobility are inevitable. Kandy is not excepted from this, where after 1970s, people settlement continues to increase. For example in 1871 the population was 16,881. By 2013 this had increased to 137,538 (Department of Census and Statistics, 2013). The resulting in, many new rehabilitations have been occurred. Indeed, the increased population and people immigration are a significant problem to develop sustainable tourism in metropolitan city like Kandy. The city of Kandy located (occupies) an area where flat and gently sloping land suitable for building purposes is extremely limited with the increase of population and economic activities as the available flat land are used up for commercial purposes, roads, streets, lanes, bus and railway station and open spaces. One of the interviewer from hotel industry he pointed that "population expansion and tourist traffic are important issue to uphold environmental sustain ability. In the case of Kandy, land price is continuously increasing”. Problems experienced commonly by Kandy which has been expanding over the last several decades without paper planning comprise the following: non - availability of adequate land, energy trained manpower and financial resources to provide facilities and auxiliaries such as clean water and sanitation to enable the city dwellers to enjoy a decent standard of living. Deterioration of the quality of natural air, water, services and land resulting from general pollution of the urban environment. Big cities of developing countries are the most seriously affected by these harms (Mc Minn, 1997; McVey \& King, 1999).

\section{Destruction of Heritage Building and Natural Beauty}

Interview with stakeholders reveals that due to the unplanned tourism development strategies adopted in Kandy was subject to environmental population. Further, absence of strict policy measures to control the location of various building linked to tourism business during the early stages of tourism development has led to various 
environmental problem. It should be noted that, interviews with the tourism business operators confirm that in the case of tourism development, government is expected to involve actively, not only in creating marketing strategy, policy and legislative structures but also in executing and monitoring all tourism development activities. In many cases, government has not followed on a proper monitoring model. This is a similar finding from other developing countries (Sharpley et al., 2014; Tosun, 2001). Developers, including central government, local government and even local inhabitants, have a lack an appropriate city development and building plan. As a result, the preservation of world reputed pre- colonial and colonial heritage buildings with magnificent architecture are being negatively affected. This is confirmed by one of member from Kandyan world heritage committee, who indicated that "unplanned city development in Kandy created a challenge to enhance the tourism industry and heritage preservation". In fact, after the British occupation, many beautiful building were constructed to fulfill administrative requirements of Kandy as a political centre. Meanwhile, they have taken many actions to safeguard pre-colonial architecture, which, in fact, have historical remembrance accepted by host community. However, recently, heritage buildings were destroyed by their legal owners in order to gain the space to construct new multi storeyed buildings for residential purpose. Further, these developments reflected modern architectural design in their construction. This has, in turn, damaged the beauty and integrity of heritage site and in some cases, facades of some heritage buildings have totally compromised. Heavy construction works also adversely affected the natural micro environment (availability of light, etc.), and destroyed the unique aesthetic values of site.

\section{Conclusion}

Investigating and assessing challenges to sustainable tourism in the world heritage site Kandy situated in central Sri Lanka concludes following importance challenges;

Like many other developing countries Sri Lanka lacks key infrastructure. Although after war, government and foreign countries engage in infrastructure development. In the case a Kandy, as pointed out earlier, there is no airport, branded hotels and high way from Colombo to Kandy. Such types of infrastructure should be established.

Community participation is lacked for two main reasons. There is a few community based tourism project run by SLTDA and limited power is delegated to local people. These reasons are perceived as major disputes to be healthy of the tourism industry, and have been underscored by previous researchers Tosun and Timothy (2001), who 
further pointed that local people participation in developing countries is determined by not only political parties it is also governed social reforms. This paper suggest that serious attention has to be taken to engage local people in tourism development in several ways; educating local community about significance of this industry and also industry related legislations, training youths as tour guides or tourist facilitators, involving city beautification campaign for the tourist hotels and guesthouses, conducting art and craft exhibition and awareness programmes, organizing traditional cultural shows among the artists.

Generally, competition for Kandy as a tourist destination is increased because many world heritage sites offer sophisticated resources to tourists. Further, they adopt effective touristic product diversification strategy (Miura, 2010). To positioning the brand image on tourists mind, touristic product diversification and differentiation strategy is successfully exercised (Robin sonet al., 2008). This study underlines that as said earlier, Kandy has competitive advantages and cultural heritage and landscape that have been getting less and less priority from tourists compared with modern resources in competiveness like innovative technology and effective tourists guides system. As the result, this paper suggests to policy makers and practitioners. They should pay more concentration on application of modern technology to increase competiveness. Finally, further research will be required to develop a strategic framework to address as mentioned challenges to sustainable tourism in Kandy. When creating a strategic framework, the nature and availability of resources; legal framework; fiscal policy of the country; capacity of competitive of destination that should be taken to account.

\section{References}

Alipour, H., Vaziri, R. K., \& Ligay, E. (2011). Governance as catalyst to sustainable tourism development: Evidence from North Cyprus. Journal of Sustainable Development, 4(5), 32.

Araña, J. E., \& León, C. J. (2008). The impact of terrorism on tourism demand. Annals of Tourism Research, 35(2), 299-315.

Archer, B., Cooper, C., \& Ruhanen, L. (2005). The Positive and Negative Impacts of Tourism. In W. F. Theobald (Ed.), Global Tourism (pp. 79-102). Burlington: Elsevier.

Berry, S., \& Ladkin, A. (1997). Sustainable tourism: A regional perspective. Tourism Management, 18(7), 433-440. 
Bowen, G. A. (2009). Document analysis as a qualitative research method. Qualitative research journal, 9(2), 27-40.

Bramwell, B. (2015). Theoretical activity in sustainable tourism research. Annals of Tourism Research, 54, 204-218.

Bramwell, B., \& Lane, B. (2015). What drives research on sustainable tourism? Journal of Sustainable Tourism, 23(1), 1-3.

Bramwell, B., \& Sharman, A. (2000). Approaches to sustainable tourism planning and community participation: the case of the Hope Valley. In G. Richards \& D. Hall (Eds.), Tourism and sustainable community development. London: Routledge.

Briassoulis, H. (2002). Sustainable tourism and the question of the commons. Annals of Tourism Research, 29(4), 1065-1085.

Butler, R. W. (1999). Sustainable tourism: A state - of - the - art review. Tourism Geographies, 1(1), 7-25.

Cater, E. (1993). Ecotourism in the third world: Problems for sustainable tourism development. Tourism Management, 14(2), 85-90.

Central Bank of Sri Lanka. (1998). Economic progress of indepent Sri Lanka. Colombo: Central Bank of Sri Lanka.

Cheer, J. M., Reeves, K. J., \& Laing, J. H. (2013). Tourism and traditional culture: Land diving in Vanuatu. Annals of Tourism Research, 43, 435-455.

Clarke, J. (1997). A framework of approaches to sustainable tourism. Journal of Sustainable Tourism, 5(3), 224-233.

Department of Census and Statistics. (2013). Censes of population and housing. Colombo: Department of Census and Statistics.

Dinica, V. (2008). Challenges for sustainable tourism governance in the Netherlands. International Journal of Tourism Policy, 1(4), 335-352.

Dinica, V. (2009). Governance for sustainable tourism: a comparison of international and Dutch visions. Journal of Sustainable Tourism, 17(5), 583-603.

Drost, A. (1996). Developing sustainable tourism for world heritage sites. Annals of Tourism Research, 23(2), 479-484.

Fairclough, N., Mulderrig, J., \& Wodak, R. (2011). Critical discourse analysis. Discourse studies: A multidisciplinary introduction, 357-378.

Fernando, S., Bandara, J. S., \& Smith, C. (2013). Regaining missed opportunities: The role of tourism in post-war development in Sri Lanka. Asia Pacific Journal of Tourism Research, 18(7), 685-711.

Ferreira, S., Strydom, J., Kriel, M., \& Gildenhys, S. (2015). Tourism and development after civil war in Malange province, Angola. South African Geographical Journal, 97(2), 158-182. 
Fyall, A., \& Garrod, B. (1998). Heritage tourism: at what price? Managing Leisure, 3(4), 213-228.

Goodwin, H. (1998). Sustainable tourism and poverty elimination. Paper presented at the DFID/DETR Workshop on Sustainable Tourism and Poverty.

Gupta, S. K. (1999). Tourism in Garhwal Himalaya: Strategy for sustainable development. In D. S. Bhardwaj, O. P. Kandari, C. Manjula, \& K. K. Kamra (Eds.), Domestic tourism in India New Delhi: Indus Publishing Company.

Hall, C. M. (2011). Policy learning and policy failure in sustainable tourism governance: from first-and second-order to third-order change? Journal of Sustainable Tourism, 19(4-5), 649-671.

Hall, M. (2003). Introduction to Tourism Dimensions and Issues. Australia: Hospitality Press.

Hall, M. C. (1994). Tourism and politics: policy, power and place: John Wiley \& Sons. Hannam, K., \& Reddy, M. V. (2016). Ecotourism as the focus of the neoliberal tourism project in India. In J. Mosedale (Ed.), Neoliberalism and the political economy of tourism (pp. 89-99). New York: Routledge.

Haywood, M. K. (1988). Responsible and respective tourism planning in the community. Tourism Management, 105-118.

Hitchcock, M., King, T., V, \& Parnwell, M. (2010). Heritage tourism in Southeast Asia. In M. Hitchcock, King, V. T, \& M. Parnwell (Eds.), Heritage tourism in Southeast

Asia (pp. 1-27). Singapore: NIAS.

Hopwood, B., Mellor, M., \& O'Brien, G. (2005). Sustainable development: mapping different approaches. Sustainable Development, 13(1), 38-52.

Hunter, C. (1997). Sustainable tourism as an adaptive paradigm. Annals of Tourism Research, 24(4), 850-867.

Jamieson, W. (2000). The changes of sustainable community cultural heritage tourism. Paper presented at the Cultural, heritage management and tourism, Nepal.

Janusz, G. K., \& Bajdor, P. (2013). Towards to sustainable tourism-framework, activities and dimensions. Procedia economics and finance, 6, 523-529.

Katsumata, N. (1999). The Japanese overseas travel market: Challenges and prospects. In P. Kee \& B. King (Eds.), Asian - Pacific Tourism regional cooperation, planning and development (pp. 109-116). Melbourne: Hospitality Press Pty Ltd. 
Landorf, C. (2009). Managing for sustainable tourism: a review of six cultural World Heritage Sites. Journal of Sustainable Tourism, 17(1), 53-70.

Lawler, S. (2005). Disgusted subjects: The making of middle- class identities. The sociological review, 53(3), 429-446.

Lenik, S. (2013). Community engagement and heritage tourism at Geneva Estate, Dominica. Journal of Heritage Tourism, 8(1), 9-19.

Liu, Z. (2003). Sustainable tourism development: A critique. Journal of Sustainable Tourism, 11(6), 459-475.

Logan, W., \& Reeves, K. (2008). Introduction remembering places of pain and shame. In W. Logan \& K. Reeves (Eds.), Places of pain and shame dealing with difficult heritage. Uk: Routledge.

Lupton, D. (1992). Discourse analysis: A new methodology for understanding the ideologies of health and illness. Australian journal of public health, 16(2), 145150 .

Mason, P. (2015). Tourism impacts, planning and management: Routledge.

Masson, S., \& Petiot, R. (2009). Can the high speed rail reinforce tourism attractiveness? The case of the high speed rail between Perpignan (France) and Barcelona (Spain). Technovation, 29(9), 611-617.

McKercher, B. (1993). Some fundamental truths about tourism: Understanding tourism's social and environmental impacts. Journal of Sustainable Tourism, 1(1), 6-16.

McKercher, B. (1999). The unrecognized threat to tourism: Can tourism survive 'sustainability'? Tourism Management, 14(2), 131-136.

McKercher, B. (2003). Sustainable tourism development-guiding principles for planning and management. Paper presented at the National Seminar on Sustainable Tourism Development, Bishkek, Kyrgyzstan.

McMinn, S. (1997). The challenge of sustainable tourism. Environmentalist, 17(2), 135-141.

McVey , M., \& King, B. (1999). Tourism in the Pacific Island Microstates: Regional Experience and Prospects. In P. K. Kee \& B. King (Eds.), Asia - Pacific Tourism Regional co-operation, planning and development (pp. 55-73). Melbourne: Victoria

University of Technology Hospitality Press.

Merriam, S. B. (2002). Qualitative research in practice: Examples for discussion and analysis: Jossey-Bass Inc Pub. 
Miura, K. (2010). World heritage sites in Southeast Asia Angkor and beyond. In H. Michael, V. T. King, \& M. Parnwell (Eds.), Heritage tourism in Southeast Asia (pp. 103 -130). Singapore: NIAS Press.

Nižić, M., Ivanovic, S., \& Drpic, D. (2010). Challenges to sustainable development in island tourism. South East European Journal of Economics and Business, 5(2), 43-53.

Paynen, R. (1993). Sustainable tourism: Suggested indicators and monitoring techniques. In James, N. Gordon, R., Butler, \& W. Geoffrey (Eds.), Tourism and sustainable development; monitoring, planning, managing (pp. 249- 254). Ontario: University of Waterloo.

Powell, R. B., Cuschnir, A., \& Peiris, P. (2009). Overcoming governance and institutional barriers to integrated coastal zone, marine protected area, and tourism management in Sri Lanka. Coastal Management, 37(6), 633-655.

Prideaux, B. (2000). The role of the transport system in destination development. Tourism Management, 21(1), 53-63.

Ratnapala, N. (1984). Tourism in Sri Lanka: The Social Impact. Sri Lanka: Sarvodaya Vishva Lekha Publications.

Reeves, K., \& Long, C. (2011). Unbearable pressures on paradise? Tourism and heritage management in luang prabang, a world heritage site. Critical Asian Studies, 43(1), 3-22.

Robinson , L., \& Jarvie, J. K. (2008). Post- disaster community tourism recovery: the tsunami and Arugam Bay, Sri Lanka. Disasters, 32(4), 631-645.

Robinson, M. (1999). Collaboration and cultural consent: Refocusing sustainable tourism. Journal of Sustainable Tourism, 7(3-4), 379-397.

Scheyvens, R. (2011). The challenge of sustainable tourism development in the Maldives: Understanding the social and political dimensions of sustainability. Asia Pacific Viewpoint, 52(2), 148-164.

Sharpley, R. (2000). Tourism and sustainable development: Exploring the theoretical divide. Journal of Sustainable Tourism, 8(1), 1-19.

Sharpley, R. (2002). The challenges of economic diversification through tourism: the case of Abu Dhabi. International journal of tourism research, 4(3), 221-235.

Sharpley, R., \& Ussi, M. (2014). Tourism and governance in small island developing states (SIDS): the Case of Zanzibar. International journal of tourism research, 16(1), 87-96.

Sönmez, S. F. (1998). Tourism, terrorism, and political instability. Annals of Tourism Research, 25(2), 416-456. 
Sri Lanka Tourism Development Authority. (2015). Annual Statistical Report2014. http://www.sltda.1k/sites/default/files/Annual_Statistical_Report2014.pdf: Sri Lanka Tourism Development Authority.

Sri Lanka Tourism Development Authority. (2016). Monthly Statistical Bulletins 2015. http://www.sltda.lk/node/704: Sri Lanka Tourism Development Authority.

Telfer, D. J., \& Sharpley, R. (2015). Tourism and development in the developing world: Routledge.

Tisdell, C. A., \& Bandara, R. (2004). Tourism as a contributor to development in Sri Lanka: An overview and a case study. Retrieved from

Tosun, C. (2001). Challenges of sustainable tourism development in the developing world: The case of Turkey. Tourism Management, 22(3), 289-303. doi:Doi 10.1016/S0261-5177(00)00060-1

Tosun, C., \& Timothy, D. J. (2001). Shortcomings in planning approaches to tourism development in developing countries: the case of Turkey. International Journal of Contemporary Hospitality Management, 13(7), 352-359.

United Nation Environment Programme and World Tourism Organisation. (2005). Making tourism more sustainable: A guide for policy makers.

United Nation World Tourism Organisation. (2013). Sustainable tourism for development guidebook. http://icr.unwto.org/content/guidebook-sustainabletourism-development: UNWTO.

Wan, Y. K. P. (2013). A comparison of the governance of tourism planning in the two Special Administrative Regions (SARs) of China- Hong Kong and Macao. Tourism Management, 36, 164-177.

Wang, Y., \& Bramwell, B. (2012). Heritage protection and tourism development priorities in Hangzhou, China: A political economy and governance perspective. Tourism Management, 33(4), 988-998.

Weight, P. (2002). Supporting the Principles of Sustainable Development in the Tourism \& Ecotourism. Government potential Role, Current issues in Tourism, 222-243.

Wickramasinghe, V., \& Takano, S. (2010). Application of combined SWOT and Analytic Hierarchy Process (AHP) for tourism revival strategic marketing planning: A Case of Sri Lanka tourism. Journal of the Eastern Asia Society for Transportation Studies, 8, 954-969. 